\title{
Transnational Behavior in Comparative Perspective
}

The Relationship between Immigrant Integration and Transnationalism in New York, El Paso, and Paris

Ernesto Castañeda, Maria Cristina Morales \& Olga Ochoa

CMS 2 (3): 305-334

DOI: 10.5117/CMS2014.3.CAST

\begin{abstract}
This paper examines transnationalism across migrant generational statuses in three urban centers. The objective of this study is to explore how immigrant integration influences the maintenance of social and economic connections with the communities-of-origin. To accomplish this objective we examine the impact of socio-economic status and generational status (first to third) on whether respondents remit, visit their communities-of-origin, or desire to return. The data for this study is based on survey data collected in New York City, New York, U.S.A.; El Paso, Texas, U.S.A.; and Paris, France. We find that transnational practices differ across the three locations. In Paris we find evidence of reactive transnationalism - looking abroad due to exclusion in the new society. In New York, however, there is more support for resourcebased transnationalism - better legal and socioeconomic integration that allows for more transnational involvement. Transnationalism in El Paso differs from NYC and Paris in large part due to being located along the U.S.-Mexico border. Surprisingly, we find that El Paso respondents are less transnational than those in Paris or New York when it comes to remittances, visiting, and the desire to return to the sending community. We conclude by proposing a new typology of transnationalism that accentuates the contextual aspects of these practices.
\end{abstract}

Keywords: migrant transnationalism, reactive transnationalism, remittances, third generation, incorporation 


\section{Introduction}

Transnationalism can be simply defined as the back and forth movement and exchanges between migrant sending and receiving communities. Transnationalism has historically been a characteristic of migration (Espiritu, 1997; Foner, 1997; Gamio, [1930] 1971; Glenn, 2002; Massey, Alarcon, Durand, \& González, 1987; Sayad, 2004; Thomas \& Znaniecki, 1918), but it is not until recently that it has become an object of study in itself. The pioneering research on transnationalism discovered this phenomenon through ethnographic work with immigrant communities and the connections they kept with their migrant-sending communities (Glick Schiller, 2003; Levitt, 2001; R. C. Smith, 1998, 2006). For the most part, comparisons were made through secondary sources or through the comparison of fieldwork findings (Basch, Glick Schiller, \& Szanton-Blanc, 1994; Glick Schiller \& Fouron, 1998; R. C. Smith, 2003). Most recently, important articles have analyzed this phenomena from quantitative and comparative perspectives (de Haas \& Fokkema, 2011; Dekker \& Siegel, 2013; Guarnizo, Portes, \& Haller, 2003; Portes, Haller, \& Guarnizo, 2002; Snel, Engbersen, \& Leerkes, 2006). Despite such advances, the study of transnationalism has mostly been applied to the first generation and less attention has been given to the transnational behavior of the children and grandchildren of migrants. This paper seeks to narrow this gap.

In this study we examine various migrant-sending and receiving sites (New York, El Paso, and Paris) and describe transnational patterns across several immigrant generations $\left(1^{\text {st }}, 1.5,2^{\text {nd }}\right.$, and $\left.3^{\text {rd }}\right)$ to further examine the relationship between transnationalism and integration. In particular, our objectives are to examine the association between socioeconomic status and immigrant generation and whether or not 1 ) they visit the country-oforigin, 2) send remittances, and/or 3) wish to return. In addition, we evaluate the reactive transnationalism hypothesis, where negative integration results in more visits and identification with the sending community (Itzigsohn \& Giorguli-Saucedo, 2002). Furthermore, the socio-economic connections that individuals maintain with their communities-of-origin will be assessed as indicators of transnationalism. The examination of these patterns of transnationalism will focus on individuals of Latin American descent in El Paso and New York City (NYC), and individuals of North African-origin in Paris, France.

This paper is comparative on many levels (Martiniello, 2013). It compares transnational behavior across generations, models of integration, immigrant groups, and geographical settings. It utilizes descriptive statis- 
tics to examine the various patterns of transnationalism of immigrants living in three cities Paris, El Paso, and NYC. It compares two practices of immigrant integration, the American one with de facto laissez-faire multicultural immigrant integration and the French case with a republican expectation of full assimilation (Bloemraad \& Provine, 2013; Bowen, 2007; Lacorne, 2003). Lastly, it examines differential locations that allow for a comparison between remote and border forms of transnationalism, thus contributing to scholarly discussions about the degree to which geographical proximity matters in regards to transnational behavior.

\section{Transnationalism within Migration Studies}

Traditionally, migration studies in the U.S. have focused on the processes of immigrant integration into their host society (Alba \& Nee, 2003; Brubaker, 2004; Gordon, 1964; Itzigsohn, 2009). Recently, scholarly attention has turned to transnationalism. The term "transnationalism" is used in various contexts and thus requires further clarification. In its broadest sense, transnationalism is the movement of capital, people, and ideas back and forth political borders. Classic examples of transnationalism are corporations such as Sony, HSBC, or Citibank which have headquarters in one country but branches and operations across multiple nation-states (Sassen, 2001). Scholars use a transnational lens to understand a series of presences, identities, and movements that do not map easily within the geographical borders of contemporary nation-states.

Migration scholars use the term transnationalism to describe migration while taking into account the twin processes of emigration and immigration (Sayad, 2004, 2006) and the social ties that keep emigrants connected to their communities-of-origin (R. C. Smith, 2006; Tilly, 2007). This approach can also be taken for internal migration, in which case the sending and receiving communities are part of the same national territory, but may have enough cultural, ethnic, or economic differences to be studied under this methodological framework (Besserer, 2004; Fitzgerald, 2009).

Transnationalism provides a framework to simultaneously consider the role of the sending and receiving communities in migrant behavior. In contrast to migration that largely focuses on long-term settlement, transnationalism examines the social, political, and economic processes at both sending and receiving communities. Historically migration has not entailed the complete severance of ties with the sending society (Foner, 2000; Thomas \& Znaniecki, 1918). Transnational studies show the strong 
connections that migrants share with their native country (R. C. Smith, 2006). Even exiles, political refugees, asylum seekers, and those migrating to escape violence may engage in their own form of transnationalism (Dufoix, 2008). We call this "refugee transnationalism," which occurs when groups escape a political regime and engage politically in the diaspora, send money, and create plans for regime change in the country-oforigin but we do not discuss it here for lack of space.

Transnationalism gained scholarly attention in the 199os (Basch, et al., 1994; Kearney, 1995; M. P. Smith \& Guarnizo, 1998). Over the last several decades, the academic sub-field of migrant transnationalism has grown considerably. A great deal of effort has been spent on "proving" its existence by adding new case studies and debating whether it is a novel phenomenon or if it has historically existed before it was recognized and labeled as transnationalism (Foner, 2000; Morawska, 2001). Some groundbreaking work in the field includes the introduction of the concept of social remittances to discuss cultural changes at the migrant-sending side (Levitt, 1998, 2001); the documentation of the role of religious institutions in transnationalism (Levitt, 2007; Mooney, 2009; Pasura, 2011); the study of the involvement of the sending state in fostering ties with the diaspora (Cano \& Delano, 2007; Delano, 2011; Fitzgerald, 2009; Iskander, 2006; R. C. Smith, 2003), and transnational parenting (Abrego, 2009; Åkesson, Carling, \& Drotbohm, 2012; Castañeda \& Buck, 2011, 2014; Dreby, 2010; Suarez-Orozco, Todorova, \& Louie, 2002). Building upon on this literature, we ask to what extent does first, 1.5, second, and third generations engage in transnational activities (Levitt \& Waters, 2002)?

Given the relative novelty of transnationalism as a theoretical perspective and its particular emphasis on multi-sited field research as a method (Marcus, 1995), there is still a lively debate about its theoretical implications, procedural definition, and to how to operationalize it through survey data collection and analysis. More research is needed on how transnationalism interacts with migrant integration and/or migrants' desire to return to their country of birth. This gap is in part attributed to the amount of labor requited to obtain rich qualitative and quantitative data for immigrants of different generations in different locations. This articles starts to fill in this gap. 


\section{Transnational Behavior and Socio-economic Status in the Receiving Society}

Few studies address the relationship between integration and transnationalism. Among the classic works that do address this interaction - albeit in passing - some pose that when faced with low wages, a stigmatized socioeconomic position, and discrimination, immigrants look to their sending communities for the status that they perceive to be lacking in their host community (Basch, et al., 1994; Sayad, 2004; R. C. Smith, 2006). On the other hand, some researchers have used survey data to show that the more legally, culturally, and socially integrated a migrant is, the more likely it is that he or she will be able to engage in collective transnational activities (Portes, Escobar, \& Arana, 2009; Portes \& Rumbaut, 2006).

A study by José Itzigsohn and Silvia Giorguli-Saucedo (2002) is one of the most cited empirical papers discussing incorporation and transnationalism. Itzigsohn and Giorguli-Saucedo (2002) compared the transnational participation of Colombians in two New York neighborhoods, with those of residents in neighborhoods with high concentrations of migrants from the Dominican Republic in Providence, Rhode Island, and with heavily El Salvadorian neighborhoods in Los Angeles, California and Washington, DC. They note the importance of comparative analysis for understanding incorporation and sociocultural transnationalism arguing that "conclusions and theories derived from the analysis of only one immigrant group are bound to be limited in their explanatory powers" (Itzigsohn \& GiorguliSaucedo, 2002, p. 767). This paper builds on their work by comparing transnational practices across different sites using the same approach. Yet, while Itzigsohn and Giorguli-Saucedo compare immigrant groups in several U.S. cities and concentrate on the first immigrant generation, this paper extends their analysis by comparing multiple generations of immigrants living in three cities located in two different countries.

\subsection{Reactive Transnationalism and Resource Based Transnationalism}

We draw from the literature to analyze whether transnationalism - operationalized as remitting, visiting, and wishing to return - is strongest for those of high socioeconomic status (SES), and for those who are the most and the least integrated immigrants.

We use Itzigsohn and Giorguli-Saucedo's (2002) term of "reactive transnationalism" to talk about heavy engagement in transnational activity in order to ameliorate the discrimination and low social status in the place of 
destination. According to this view, high levels of transnational participation among migrants serve as a palliative and act as an escape from the effects of low social status in their host society. It is called reactive, because it is compensatory to social exclusion.

Itzigsohn and Giorguli-Saucedo's (2002) use the term "Resource Based Transnationalism" to describe how successful integration and economic success in the place of destination can also lead to high levels of transnationalism. Biculturalism and other forms of interaction with the countryof-origin can be sources of pride, uniqueness, and increased social status for successful and structurally integrated immigrants. Under this scenario, migrants are able to successfully engage with people in their country-oforigin, because of the migrants' achievements and accumulated resources (Portes \& Rumbaut, 2006). As such, successful immigrants and their progeny have the resources to "maintain a foot in both worlds" and draw from the benefits of brokering between the two societies (Kasinitz, Mollenkopf, Waters, \& Holdaway, 2008, p. 20).

Reactive transnationalism and resource base transnationalism can also be considered in terms of associations between transnationalism and integration. For instance, migrant integration is positively correlated to transnational participation such that the more legally, culturally, economically, and socially integrated a migrant is, the more likely he or she will be to engage in collective transnational activities (Portes, et al., 2009; Portes \& Rumbaut, 2006), which supports the resource based transnationalism perspective. Yet, transnational activity may also be high when immigrant integration is very low, or when the immigrant is faced with low wages, a stigmatized socio-economic position, and racialization (Sayad, 2004; R. C. Smith, 2006). In these situations immigrants may look to the sending communities for the status that they lack in their host community. For example, dark skinned immigrants from the Caribbean may be categorized as blacks in New York and Boston, but in their country-of-origin their identity is not determined solely by skin color (Basch, et al., 1994; Levitt, 2001; Roth, 2012).

\section{$4 \quad$ Methods and Data}

Data for this study comes from ethno-surveys - which collect quantitative data, open-ended narratives, and contextual information (Massey, 1987; Massey \& Zenteno, 2000) - conducted in Paris, France $(\mathrm{N}=65)$, New York City, New York, USA (N=363), and El Paso, Texas, USA (N=1038). Ethno- 
surveys with similar questions were written in English and translated into Spanish and French. The surveys were conducted by the first author and trained research teams at different times: Paris (2007-2008), New York City (2009-2010), and El Paso, Texas (2011-2012). Insights also come from extensive fieldwork conducted by the first author in Paris, New York, El Paso, and in migrant-sending communities in Mexico, Morocco, and Algeria.

El Paso is a traditional migrant destination, historically a gateway city for immigrants from Mexico with a considerable population of $3^{\text {rd }}$ and later immigrant generations. Data for New York is restricted to Latina/o immigrants (mostly Dominicans, Puerto Ricans, and Mexicans). In contrast to El Paso, Mexican migration to New York is much more recent and only got intensified in the last 30 years (Smith, 2006). Puerto Ricans in the New York (44) and El Paso (2) samples were included in the analysis as "transnationals" because despite being U.S. citizens from a U.S. territory their movement to and from the island and experiences with social integration in the mainland U.S. parallel those of other Latina/os.

The comparison is made with North Africans in the Paris metropolitan area. France was a colonial power in the North African countries of Algeria, Morocco, and Tunisia; this created early migration flows to Paris (Lucassen, 2005; Sayad, 2006; Silverstein, 2004). Current migration from North Africa to France has slowed and is mainly driven by family reunification.

In contrast to studies that only survey immigrants who are perceived to exhibit high levels of transnational behavior due to their membership in hometown associations or ownership of ethnic businesses, we recruited respondents from across the metropolitan regions in question in order to be able to speak about transnational behaviors in and beyond ethnic enclaves (Castañeda, 2012a).

It is extremely difficult to use traditional random sampling strategies to survey migrants and especially undocumented immigrants, because they are highly mobile, hidden, and vulnerable populations (Singer, 1999). Therefore we used purposeful sampling techniques (Neuman, 2011). In particular, we sampled with the following considerations in mind, a) heterogeneity of respondents (different ages, professions, education levels, and immigrant generational statuses), b) representation of all main geographic areas in the cities and towns studied (Castañeda, 2012a), and c) saturation of responses, stopping when new answers continued to echo previous ones (See table 1). Surveys were conducted face to face. 
Table 1 Sample Descriptive Statistics

\begin{tabular}{|l|c|c|c}
\hline & El Paso & NYC & Paris \\
\hline Mean Age & 36.42 & 32.63 & 32.18 \\
\hline (Std. Dev.) & $(15.57)$ & $(11.68)$ & $(12.41)$ \\
\hline Percent Female & 54.2 & 51.2 & 24.6 \\
\hline Percent Latinos & 100 & 100 & 0 \\
\hline Percent North African & 0 & 0 & 100 \\
\hline Percent Undocumented Migrants & 6.4 & 18.9 & 0 \\
\hline Years of Education Mean & 12.54 & 13.56 & 13.37 \\
(Std. Dev.) & $(3.62)$ & $(3.24)$ & $(3.29)$ \\
\hline Sample Size & 1038 & 363 & 65 \\
\hline
\end{tabular}

\subsection{Operationalization of Variables and Data Analysis}

The dependent variables are indicators of transnationalism based on the following questions:

Do you go back to visit your town/city of birth [or that of your parents]? $(1=$ yes, $0=$ no);

Do you send money back to your town/city of birth [or that of your parents]? $(1=$ yes, $0=$ no);

Do you plan to move back to your town/city of birth [or that of your parents]? ( $1=$ yes, $0=$ no);

Do you think your life is better as a result of migrating? $(1=$ yes, $0=n o)$.

The survey data was entered and analyzed with the SPSS 21 statistical package. Descriptive statistics and bivariate analysis were used to examine the research objectives. Data was analyzed for each location individually, because different sample sizes and frames impede the usage of statistical tests to compare across locations. The statistics are provided for descriptive analysis and theory making. The specific quantitative results are not meant to be generalizable to the whole immigrant and ethnic population of the city in question. Therefore the small samples and differences in sample size do not affect the descriptive analyses and the hypothesis advanced.

A primary independent variable is immigrant generation. We define the first generation as those born abroad and immigrating after 16 years of age. We define the 1.5 generation as those who migrated before the age of 16 . The second immigrant generation is defined as those born in the country of residence with at least one parent born abroad. We define the third generation as when some or all grandparents were born abroad. The second and third generation individuals are citizens of the respective countries in which they reside given that both the U.S. and France have established jus soli laws (Brubaker, 1992; Weil, 2005). 
The second independent variable is socio-economic status. This variable was created to assess the resource-based transnationalism hypothesis. We divided our samples into low, medium, and high Socio-Economic Status (SES). In El Paso, SES is an index measure consisting of occupation, years of education, and yearly household income (low = less than $\$ 30,000$; middle = $\$ 30,001-\$ 60,000$; and high = more than \$6o,001; all figures in U.S. dollars). In New York and Paris, SES is an index consisting of occupation and years of education. The operationalization of SES as low, medium, and high in these locations was also informed by ethnographic data that helped to contextualized how SES or class is conceptualized differently across locations. To code the SES variable, members of the research team with at least one year of field experience in each location determined the cutoffs for low, medium, and high SES. We used inter-coder reliability methods to assess the coding consistency. Initially each coder categorized cases independently; then, the coders met to compare codes and agreed on a code in case of disagreement. Given that SES is relational and thus varies across locations, we believe that this qualitative assessment is an improvement to pure self-report or a quantitative measure based on only one dimension.

Asking people of Algerian-origin in Paris if they plan to go back to live in Algeria is a very sensitive topic, given that many French people often ask them the question rhetorically as a push out of the country. I often heard French individuals asking "Why do Algerians migrate to France if they wanted Algeria to become independent from France?" Thus the direct question about return was taken out of the ethno-surveys conducted in Paris. While this question was not asked directly of North Africans, interviewees were asked if they would like to live in another country if they could, and they were also asked how their lives would be different if they lived in the country-of-origin. Those who answered that they wished they could live in their country-of-origin or their family's ancestral home, and those who explicitly brought up return migration, were coded as wishing to return. We were able to capture the desire to return in this manner, but we suspect that this may have resulted in an underestimation of the wish to return among North Africans in France.

\section{Multi-sited Comparisons of Transnational Behavior}

By comparing immigrant integration patterns and transnational behavior in different receiving cities and countries, interesting patterns appear. Figure 2 illustrates a summary of the transnational behaviors in all three 
locations. The sample of residents of North African origin living in Paris demonstrated the highest percentage of people visiting the country-oforigin and desiring to return. The percentage of those remitting is slightly higher for New York than Paris, and much lower in El Paso.

Latina/os in El Paso experience transnationalism somewhat differently than the respondents in the other locations. They are less likely to visit their place-of-origin, less likely to remit, and much less likely to wish to return. These outcomes point to the role of geographic proximity in shaping transnationalism. People residing in El Paso can visit Ciudad Juárez, Mexico with relative ease (if they have proper documentation). Additionally, it is possible that respondents remit money through Mexican channels or via the visitation of people from Ciudad Juárez and Northern Mexico. We will elaborate more on this issue below.

The transnational behavior of El Paso residents also varies in terms of visitation to the place-of-origin. We suspect that for many immigrants from other parts of Mexico visiting Ciudad Juárez may be enough to take what Robert Smith (2006) calls "a long drink of mexicanidad." El Paso itself may also fill the need to connect with Mexican culture. El Paso is 83 percent Latina/o, mostly Mexican, with the majority of the population speaking Spanish and embracing Mexican culture. Therefore, residing in El Paso can diminish the nostalgic elements Mexican immigrants usually have, which reduces the need to return to the home country except for family visits and functions. Border dynamics both distance and connect U.S. residents to and from Mexico (Heyman, 2012; Vila, 2000).

In the following graph we provide a summary of transnationalism practices such as visits, remittances, and desire to return.

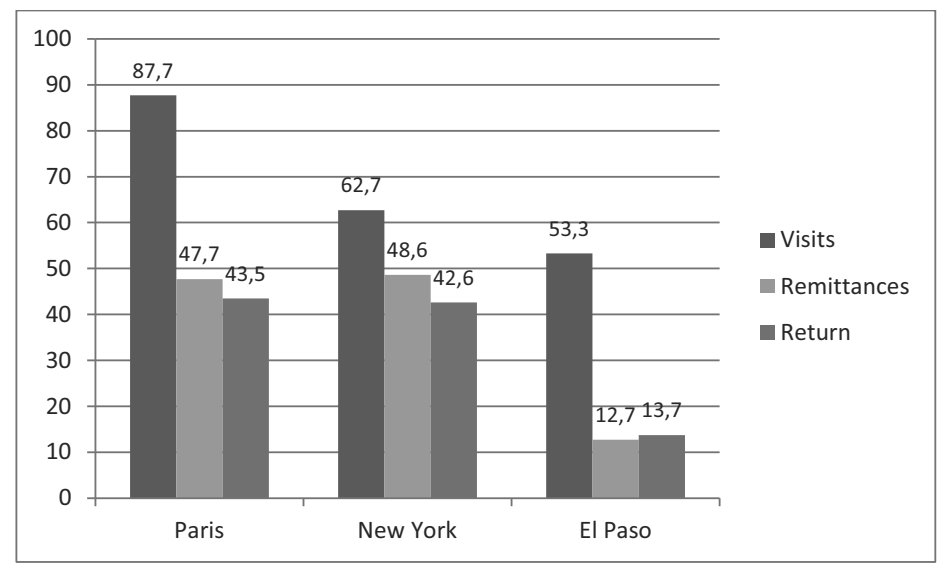

Figure 2 Percent Remittances, Visits, and Wish to Return Paris, New York, El Paso 
Figure 2 shows the percentage of respondents who sent remittances or visited their hometown or ancestors' place-of-origin for all SES and immigrant generations.

\section{Socioeconomic Status and Tendency to Visit, Remit, and Desire to Return to Hometown or Ancestral Place- of-origin}

\subsection{Remittances and SES}

Table 3 Percent Remittances by SES, El Paso, New York, Paris

\begin{tabular}{l|l|l}
\hline El Paso & \multicolumn{2}{c}{ Chi Square } \\
\hline Low & 13.8 & 1.903 \\
Medium & 10.5 & \\
High & 10.8 & \\
Total & $\mathbf{1 2 . 9}$ & \\
\hline NYC & & 1.300 \\
\hline Low & 50.9 & \\
Medium & 46.7 & \\
High & 41.9 & \\
Total & $\mathbf{4 8 . 2}$ & $4.631^{*}$ \\
\hline Paris & & \\
\hline Low & 38.7 & \\
Medium & 68.4 & \\
High & 40 & \\
Total & $\mathbf{4 7 . 7}$ & \\
\hline *p. $<.1$ & & \\
\hline
\end{tabular}

High remittance activity was found in Paris (47.7\%) and in New York City (48.2\%); it was considerably less in El Paso (12.9\%). While the low level of economic remittances in El Paso may be a surprising, there are several reasons that explain this outcome. First, we suspect that the low-level of economic remittances is attributed to the proximity to Ciudad Juárez, Chihuahua, Mexico. Being at the U.S.-Mexico border makes it easier for El Paso residents to receive visitors from Mexico. Indeed, results show that over half (51.6\%) of all Latina/os surveyed in El Paso receive visitors from their place-of-origin, which means that the Latina/o residents can provide economic support for family members who come to visit. This is particularly the case for the first and 1.5 generations who received the most visits. It is also possible for Latina/os who have family members in Mexico to send money directly or through family/friends and not think of this as 
"remittances" given that they do not have to rely on Western Union or other financial intermediaries. Moreover, there are many second and third generation immigrants, who are settled in El Paso and therefore have fewer ties to their sending communities. This translates into lower participation rates in these transnational activities with only about half of first generation Latina/os sending money, and 2.3 percent of the third generation sending remittances (table 7 ).

When examining variations by SES we find that in Paris, North Africans with medium SES remit the most of any group (68.4\%), while low and high SES groups have much lower and comparable percentages $(38.7 \%$ and $40 \%$ ). On the other hand, there are some indications of reactive transnationalism in New York City and El Paso. In particular, New York City, Latina/os with low SES are more likely to remit (50.9\%), followed by medium (46.7\%), and high SES (41.9). Thus, in NYC the low-wage immigrants display the highest levels of economic transnationalism. In El Paso Latina/os with low SES are more likely to send remittances (13.8\%), while about 10.5 percent of individuals with high and medium SES remit (chisquare $7.047, \mathrm{p}<.05)$.

\subsection{Visits and SES}

Table 4 Percent Visits to Hometown by SES, El Paso, New York, Paris

\begin{tabular}{l|l|l}
\hline El Paso & \multicolumn{2}{c}{ Chi Square } \\
\hline Low & 51.9 & $6.571^{*}$ \\
Medium & 62.4 & \\
High & 44.4 & \\
Total & 53 & \\
\hline NYC & & $9.973^{* *}$ \\
\hline Low & 54.7 & \\
Medium & 70.2 & \\
High & 74.4 & \\
Total & 62.7 & $.666^{\mathrm{a}}$ \\
\hline Paris & & \\
Low & 87.1 & \\
Medium & 84.2 & \\
High & 93.3 & \\
Total & 87.7 & \\
\hline${ }^{*}$ p. $<.05$ & & \\
\hline
\end{tabular}

** p. <.01 ${ }^{\mathrm{a}}$ Few answered "No" across SES, making the x2 meaningless 
Next we examine another form of transnationalism - visits to the countryof-origin. Examining the percentage of respondents who visit their placesof-origin, Paris $(87.7 \%)$ is the most transnational, followed by New York $(62.7 \%)$, and El Paso (53\%). Below we examine whether respondents visited the country-of-origin varies by SES in all locations.

In Paris, across all socioeconomic statuses a great majority of respondents visited their countries-of-origin. Specifically, those with high SES visited the most $(93.3 \%)$, but it is not remarkably higher than those with low $(87.1 \%)$ or medium SES $(84.2 \%)$. There is a considerable percentage of Maghrebi French who no longer have close relatives to remit to, yet they keep visiting their country-of-origin (see section on return). Regardless of the socioeconomic status of French residents of North Africanorigin, they are very likely to visit their ancestral home-country. This seems to support the reactive transnationalism hypothesis, where involvement in transnational activity is a way to deal with discrimination and limited social statuses in the receiving community. In terms of discrimination, 46.2 percent of first generation and 50 percent of the second generation of North Africans in Paris reported being negatively affected by reactions to their skin color (see Table 7). Maghrebis in Paris report more frequent visits home in comparison to Latina/os in New York. Analysis conducted (but not shown) illustrate that multiple immigrant generations of Maghrebis with varying degrees of social status and levels of education, have high levels of transnationalism in terms of the number of visits to North Africa, also supporting the reactive transnationalism hypothesis.

In New York, Latina/o migrants with lower SES are less likely to visit the country-origin. Specifically, 74.4 percent of those with high and 70.2 percent of those with medium SES visit their country-of-origin compared to only 54.7 percent of those with low SES (chi square $=9.973$, p.<.o1) (Table 4). Thus, the results for New York respondents in terms of visits to the country-of-origin are more reflective of resource-based transnationalism where successful integration also encourages transnationalism.

In El Paso, those of medium SES were most likely to visit the sending community or family's place-of-origin (62.4\%), which is not necessarily Ciudad Juárez, followed by Latina/os with low SES (51.9\%), and those with high SES $(44.4 \%)$ (chi square $=6.571$, p.<.05). The question does arise about why the visits to the country-of-origin are not higher in El Paso given the proximity to Mexico. To start with, El Paso is a heavily militarized border with long waiting lines to cross the international 
bridges. Moreover, El Paso offers ample Mexican food products, and Spanish is widely used. As such, it satisfies the yearning to visit Mexico for nostalgia as discussed earlier. Also, since the outbreak of the cartel wars in Mexico, going to Ciudad Juárez has become more dangerous, deterring many from visiting (Campbell, 2009; Morales, Morales, Menchaca, \& Sebastian, 2013).

The question could be raised of whether Latina/os visit Ciudad Juárez instead of visiting their hometown or place-of-origin. Table 5 differentiates between visits to Ciudad Juárez and the sending community for Latina/os in El Paso. To start with, about 59 percent of those who are born in Juárez visit the city. Among those who were born in other parts of Northern Mexico about 52 percent visit Juárez and about 55 percent visit their sending community (in this case other locations in Northern Mexico that are not Juárez). Among those born in Southern Mexico and who reside in El Paso, 57 percent visit Juárez, but only about 45 percent visit their sending community. In this case we see that geographical distance does play a role in decreasing the likelihood of visiting the place-of-origin. Those from Southern Mexico visit home less than those from Northern Mexico and less than those from Ciudad Juárez. This signals that visiting Ciudad Juárez may partly satisfy the wish to experience Mexico without having to spend the time and money necessary to return to their sending community. In the following table, we differentiate between visiting El Paso's cross-border city of Ciudad Juárez and visiting more interior parts of Mexico (see Table 5).

Table 5 Percent of Transnational Movements of Foreign-born Mexicans in El Paso

\begin{tabular}{ll|l}
\hline Place of Birth & Visits to Juarez & Visits to Sending Community \\
\hline Ciudad Juarez & 59.3 & 59 \\
Northern Mexico & 52.3 & 54.6 \\
Southern Mexico & 57 & 45.4 \\
\hline
\end{tabular}

\subsection{Desire to Return by SES}

A question that is becoming more central to the literature is return migration (Gmelch, 1980). Figure 6 presents data on the desire to return by SES and location. Overwhelming, Latina/os in El Paso have little desire to return (14\%), while in New York and Paris approximately 40 percent of individuals wish to return. Examining variations by SES, in El Paso there are some indications of reactive transnationalism with those with low SES being almost twice as likely to wish to return $(16.2 \%)$ than those with medium SES (6.8\%) (chi square $=7.980$, p.<.05). However, 
Latina/os with high SES occupy a mid-level position in terms of desire to return (9.8\%). In New York, there are no striking differences among the social classes with about 40 percent of Latina/os in each SES strata wishing to return. Similarly in Paris, slightly over 40 percent of low and middle class Latina/os wish to return, while 46.7 percent of high SES Latina/os wish to return.

Table 6 Percent Desire to Return by SES, El Paso and New York

\begin{tabular}{l|l|l}
\hline El Paso & \multicolumn{2}{c}{ Chi Square } \\
\hline Low & 16.2 & $7.980^{*}$ \\
\hline Medium & 6.8 & \\
\hline High & 9.8 & \\
\hline Total & 14 & .423 \\
\hline NYC & & \\
\hline Low & 42.2. & \\
Medium & 40.2 & \\
\hline High & 46.2 & \\
\hline Total & 42 & .081 \\
\hline Paris & & \\
\hline Low & 42.9 & \\
\hline Medium & 42.1 & \\
\hline High & 46.7 & \\
\hline Total & 43.5 & \\
\hline * p. $<.05$ & & \\
\hline
\end{tabular}

\section{Transnational Activity, Immigrant Generation, and Social Integration}

Some interesting patterns in transnational behavior appear when examining the results by generational status. In El Paso, first generation immigrants visit their place-of-origin more than other generations. In contrast, the 1.5 and second generation Latina/os in New York visits more often than the first generation. In the New York sample, 61.9 percent of first generation immigrants send remittances. This is consistent with data that indicates that first generation migrants in New York stressed that the primary reason for migration was to send remittances home. Immigration into El Paso, on the other hand, is historically older and there are more individuals of second and higher generations who remit less.

In El Paso the plans of return are relatively low across generations. The 
Table 7 Transnational Behavior and Incorporation by Immigrant Generation

\begin{tabular}{|c|c|c|c|c|c|c|c|c|c|c|}
\hline & \multicolumn{4}{|c|}{ El Paso Latinos } & \multicolumn{4}{|c|}{ NYC Latinos } & \multicolumn{2}{|c|}{ Paris* N.Africans } \\
\hline & $1^{\text {st }}$ & 1.5 & $2^{\text {nd }}$ & $3^{\text {rd }}$ & $1^{\text {st }}$ & 1.5 & 2 & 3 & $1^{\text {st }}$ & $2^{\text {nd }}$ \\
\hline \multicolumn{11}{|l|}{ Transnational Behavior } \\
\hline$\%$ visit place or origin & 60.8 & 47.3 & 51.4 & 41.2 & 56.2 & 72.2 & 64.1 & 50 & 88.9 & 92.3 \\
\hline$\%$ parents visit place of origin & 44.3 & 48.9 & 56.5 & 46 & 33.9 & 48.9 & 48.1 & 30 & 81.3 & 95.8 \\
\hline$\%$ remit & 51.9 & 23.7 & 22.1 & 2.3 & 61.9 & 48 & 25.6 & 11.1 & 55.6 & 50 \\
\hline$\%$ wish to return & 17.4 & 7.5 & 14.7 & 8.8 & 48 & 39.6 & 36.8 & 20 & 60 & 32 \\
\hline \multicolumn{11}{|l|}{ Incorporation Variables } \\
\hline Mean years abroad (Std. Dev.) & $\begin{array}{c}18.43 \\
(14.07)\end{array}$ & $\begin{array}{c}28.31 \\
(13.78)\end{array}$ & - & - & $\begin{array}{l}14.17 \\
(9.48)\end{array}$ & $\begin{array}{c}20.408 \\
(9.82)\end{array}$ & - & - & $\begin{array}{c}11.15 \\
(15.36)\end{array}$ & - \\
\hline$\%$ Better off post-migration & 90 & 96.9 & 91.2 & 89.1 & 90.5 & 91.4 & 94 & 90 & 31.3 & 28.6 \\
\hline \multicolumn{11}{|l|}{$\%$ SES } \\
\hline Low & 76.6 & 59.9 & 50.7 & 61.7 & 58 & 49.5 & 42.5 & 28.6 & 33.3 & 53.8 \\
\hline Middle & 21.3 & 32.7 & 40.6 & 32.7 & 34 & 34.3 & 38.8 & 64.3 & 29.6 & 26.9 \\
\hline High & 2.1 & 7.4 & 8.6 & 5.6 & 8 & 16.2 & 18.8 & 7.1 & 37 & 19.2 \\
\hline $\begin{array}{l}\text { \% Negative effects due to skin } \\
\text { color/physical appearance }\end{array}$ & 6.9 & 7.7 & 14.1 & 18.5 & 14.5 & 12 & 7.2 & 14.3 & 46.2 & 50 \\
\hline \% Belonging & 59.5 & 61.1 & 63.3 & 54.6 & 68.7 & 73.9 & 61.3 & 76.9 & 19.2 & 19.2 \\
\hline $\mathrm{N}$ & 309 & 168 & 390 & 171 & 166 & 100 & 83 & 14 & 27 & 26 \\
\hline
\end{tabular}


$1^{\text {st }}$ generation has the highest percentage of people planning to move back but less than twenty percent. In contrast, almost half of first generation Latina/os in New York dream of going back to Latin American or the Caribbean (48\%). Qualitative studies of North African migration in Paris indicate that the desire to return is very high across generations and especially for Algerians (Sayad, 2006). The qualitative data gathered shows a certain "dream of return" paired with an understanding of the low feasibility of such a possibility (see section on return below).

To measure socioeconomic integration of newcomers, we include years living abroad and prospects of social mobility in comparison with that of others in the country-of-origin. These data were only reported for the first and 1.5 generation (Table 7 ).

In regards to social integration, Latina/os in El Paso feel more integrated into the community. An overwhelming majority, go percent and above, of Latina/os in El Paso and in New York perceive they were better off after migration. North Africans in Paris, on the other hand, are less certain about their upward mobility. In El Paso and New York, experiences with discrimination were similar across generational status. Moreover, higher levels of discrimination were reported in New York than in El Paso. An openended social integration question concerned whether immigrants "felt part of a community" and we find important variations by generational status. In El Paso, a bicultural border community, it is the second generation that feels the most integrated into a community; on the other hand, in New York it is the third generation that had the highest degree of social integration $(76.9 \%)$. The qualitative data contextualizes the quantitative findings. For instance, many dark-skinned and informally dressed Latina/os reported being racially profiled by the New York Police Department in the streets and specially in the subway, yet they did not feel overwhelmingly discriminated against in the city at large. Many Parisian immigrants also mentioned having experienced racism and racial profiling in the metro. Furthermore, in Paris many individuals of North African-origin saw themselves as "foreigners" despite being citizens. Hometown associations and ethnic organizations are not perceived positively in Paris (Castañeda, 2012b). Indeed, most North Africans in Paris have internalized the French rejection of religious and ethnic clubs, although they continue to feel excluded from the local and national French community. Indeed, French North Africans feel stigmatized, regardless of their citizenship status, and often live in residentially segregated neighborhoods (Castañeda, 2012a). 


\section{Reactive Transnationalism and the Barriers to Return}

In this section we introduce qualitative data associated with the high levels of exclusion and discrimination among North Africans in Paris (Beaman, 2012; Castañeda, 2012a). Many French people of North African-origin find meaning and validation through going back home -the bled as they call it. Samir, a beur (French citizen whose family comes from the Kabylia region of Algeria) is at the end of a sejour (short stay) in the Kabylie area of Algeria, claimed:

As a kid, I did everything not to come here [town in mountainous rural Algeria], at least 1,00o meters high, without water or electricity. I had the impression of living in hell. Today, there is not one year when I don't say to myself, man how are you going to find a way in your crazy life to come for some days and say hi to your ancestors' land ... A visceral need to find myself there, to find again the smells, the sounds that make a memory; To listen to ... a neighbor talk to me in Kabyle, that beautiful language .... To place myself in the terrace of a café and to see in front -to discover like if it was the first timethose mountains, majestic and proud ... you feel proud of yourself because you have understood a little more what happiness is like... ${ }^{1}$ (Samir 2012).

The quote above demonstrates how essential the homeland becomes for migrants, and the yearning to return not only to reconnect with the home community but to regain their sense of pride and happiness. In this case these visits are embedded with childhood memories that became more valuable as he matured. Samir describes the language and physical beauty of Kabylia, but the quote also conveys a sense of pride associated with his homeland. This can be understood as being in implicit contrast to his life experiences in France. He wrote the words quoted above on his Facebook page in October 2012, to which a friend of his replied:

Magnificent vision of reality, happiness is at the place-of-origin. I do not speak only for myself; my country [France] disappoints me [more] day by day. I find joy and hope in my friends from the Maghreb that have in them the charm, the life, and everything else from that beautiful region. But oh well, one struggles to be happy wherever God has placed us! ${ }^{2}$

This quote and the response epitomize how French citizens of North African-origin often create an idealized contrast between their homeland and France. Yet moving back to North Africa is unlikely for these migrants 
because of the cultural differentiation or "dissimilation" that immigrants face vis-à-vis the country-of-origin (Fitzgerald, 2009). Even these nostalgic visits are often plagued with conflicting emotions:

You are lucky... and I am happy for you! I had the goose bumps imagining your visit. I love my [bled] homeland so much... In regards to myself, I am apprehensive to go there because of administrative pressures and other reasons... after our last visit, my daughter has promised not to set foot there again ... Unfortunately, I feel like a stranger in my country, like I feel a stranger in France always because of the racists that lead this country! [Jasmin] ${ }^{3}$

People change after emigrating and may longer fit in the country-of-origin after leaving (Fitzgerald, 2009). Furthermore, the sending places also change. Interviewees provided evidence about the illusiveness of return in the open-ended questions in the ethno-survey. For example, a North African in Paris wrote: "In Algeria there have been changes for the worse; you no longer find your points of reference. I returned in 1994 and I did not recognize my village. There had been much rural immigration to the town." 4

These sentiments share a likelihood to the experiences of Mexican Americans who often feel that they are "neither from here nor from there," that they are "not Mexican enough for Mexicans nor American enough for Americans" (Jiménez, 2010). Their return to Mexico is therefore neither a feasible nor preferred option. As table 6 shows, the number of Latina/o immigrants who report that they plan or would like to return to their country of birth or that of their ancestors is very low except among the first and 1.5 generations in New York. For example, Lucia, a Mexican immigrant, says:

I think that I am divided... "I consider Mexico my home, but I think of my home as [the United States] because here I have had many opportunities and this is where I live. So I am confused when I think about home (Boehm, 2012, p. 31)

Permanent return migration is often not realistic so transnationalism can either be a state of limbo or it may allow immigrants to try to enjoy the best of both worlds. It is clear that although Lucia thinks partially of these two countries as her home and feels fragmented when thinking about home. This is especially the case when it comes to family celebrations, because she is part of a transnational nuclear family. Despite the fact that 
these families find ways of preserving relationships that transcend the border; physical barriers, laws, and scarce resources pose real challenges to family unity (Castañeda \& Buck, 2014). Another barrier for permanent return migration is the lack of financial success in the receiving society and the shame associated with that. One interviewee explains:

[In the United States] I go from the house I live in to work and from work back to the house. I do not go out often. I miss my hometown. I wish I could go back... [but] I cannot. I have not saved enough. The people would laugh at me. They would say that I am a failure that I did not succeed and that I came to the U.S. for nothing (Abraham, Guerrero, August 2006).

As the quote above illustrates even if first generation immigrants are not economically successful or happy abroad, they do not think about returning as the best solution. Exceptions to this pattern are when immigrants are responding to large structural changes like an economic crisis that drastically increases unemployment among immigrants. Returning under these conditions is not as stigmatized because it is not perceived as the immigrant's fault.

\section{$9 \quad$ Discussion and Conclusions}

Based on ethno-survey data from Paris, New York City, and El Paso we illustrate the contextual aspects associated with some transnational practices. As such, geography matters and shapes transnational behavior. In particular, we find that the relative geography of the sites of origin and destination shape transnationalism behavior. Thus, we suggest a new typology for understanding transnationalism. We propose to differentiate between "remote transnationalism" - where individuals' country-of-origin is farther away in contrast to being in close proximity to the country-oforigin - and "border transnationalism" - where there is physical and cultural proximity to the country-of-origin.

We have compared transnational practices (remittances, visits, desire to return) in three very different urban contexts. We compared transnational behavior within urban centers across SES and immigrant generation. An interesting finding is that closeness to the border does not translate to more visits, remittances, or desire to move back to the home country as would one expect. Indeed many residents of El Paso rarely visit Mexico even though it is relatively cheaper and easier to visit. We suspect that this 


\begin{tabular}{|c|c|c|c|}
\hline & Reactive Transnationalism & Resource-based Transnationalism & Border Transnationalism \\
\hline Arguments & $\begin{array}{l}\text { Occurs when immigrants and their descendants are } \\
\text { not satisfied with their standing in their new society. } \\
\text { Transnationalism appears as nostalgia for a better } \\
\text { past, and the idealization of a better future outside of } \\
\text { poverty and racialization within the host society. }\end{array}$ & $\begin{array}{l}\text { Individuals in this category have the legal status and } \\
\text { the economic resources needed to cross political bor- } \\
\text { ders back and forth with ease. This transnationalism } \\
\text { and cosmopolitanism is resource based (Calhoun, } \\
\text { 2003). }\end{array}$ & $\begin{array}{l}\text { Occurs among the individuals and organizations } \\
\text { which experience a constant crossing of international } \\
\text { borders for economic, social, and cultural reasons. The } \\
\text { port of entry is also in geographical proximity. Yet it } \\
\text { does not mean that all border residents remit or cross } \\
\text { often. }\end{array}$ \\
\hline Assumptions & $\begin{array}{l}\text { Countries have mutually exclusive cultures and one } \\
\text { may have to look elsewhere for better religious and } \\
\text { cultural integration. }\end{array}$ & $\begin{array}{l}\text { May be seen as the weakening of the nation state } \\
\text { (Sassen, 1996), post-national membership (Soysal, } \\
\text { 1994), and citizenship à la carte (Fitzgerald, 2009). }\end{array}$ & $\begin{array}{l}\text { People can go back and forth freely in a border city } \\
\text { when they have the proper documents (if crime is } \\
\text { low in both sides of the border). }\end{array}$ \\
\hline The Implied Effects & $\begin{array}{l}\text { Transnationalism is practiced to obtain the dignity, } \\
\text { identity, and cultural purity lost by family's migration } \\
\text { and downward assimilation. Transnationalism often } \\
\text { remains aspirational since a return is not practical and } \\
\text { many cultural differences remain. }\end{array}$ & $\begin{array}{l}\text { Transnationalism erases border flows and allows for } \\
\text { new business and cultural connections but is limited } \\
\text { to a small group. This is true of professionals, scien- } \\
\text { tists, and elites but cannot be generalized to all mi- } \\
\text { grants. }\end{array}$ & $\begin{array}{l}\text { It is embodied in bilingualism and biculturalism and } \\
\text { is a form of everyday transnationalism, e.g. people } \\
\text { living in Ciudad Juárez, Mexico but working or } \\
\text { studying in El Paso, Texas, USA who do not remit per } \\
\text { se but carry cash with them and spend it in either } \\
\text { country. Border residents may experience many of } \\
\text { the positive effects of transnationalism without the } \\
\text { need to remit or visit often. }\end{array}$ \\
\hline Implications Regarding & Remittances are not part of the return aspirations of & Educated cadres, professionals, and business owners & Brokerage, back and forth movement as a strategy to \\
\hline $\begin{array}{l}\text { Remittances and Devel- } \\
\text { opment of Sending } \\
\text { Community }\end{array}$ & $\begin{array}{l}\text { second and third generation individuals since they have } \\
\text { little money to remit and few family members to remit } \\
\text { to. Transnationalism expresses itself more through nos- } \\
\text { talgic tourism, music, and cultural consumption. }\end{array}$ & $\begin{array}{l}\text { can make productive investments in host and sending } \\
\text { countries and help through charitable donations yet } \\
\text { the number of people in this position is relatively } \\
\text { small (0ng, 1999; Saxenian, 2006). }\end{array}$ & $\begin{array}{l}\text { overcome poverty and marginalization. Contingent on ci- } \\
\text { tizenship, residency or visas (Campbell \& Lachica, 2013). }\end{array}$ \\
\hline
\end{tabular}


is in part attributed to the recent increase in insecurity and in Mexican culture being a large part of El Paso's society. El Paso also varied from New York City and Paris in terms of plans for return migration and economic remittances. These different dynamics at the U.S.-Mexico border leads us to conclude that there is a "border transnationalism" shaped by proximity to the home country.

Table 8 illustrates the variations among different forms of transnationalism including those in the literature (reactive transnationalism and resource-based transnationalism), which are types of remote transnationalism in contrast to border transnationalism that we are proposing.

The table above (Table 8) points to new directions in which to examine several forms of transnationalism. Examining some transnational patterns - remittances, visits to the country-of-origin, and desire to return - was fruitful to illustrate the various dynamics involved in transnationalism. Moreover, examining how transnationalism occurs in three different cities (El Paso, New York, and Paris) and among two different groups (Latina/os and North Africans) points to the importance of contextualizing transnational behaviors. Below we highlight some specific findings.

First, SES does not consistently predict remitting behavior; it had some influence on visiting the ancestral nation and in the desire for return migration in both New York and Paris. Specifically, in Paris, those of medium socioeconomic status remit the most. This may be attributed to the fact that those who are of the lowest socio-economic strata in Paris are unemployed in our sample and therefore do not have funds for economic remittances. Those with high SES, on the other hand, can afford to bring their whole family to France to visit and are also the most likely to be granted proper documentation for their family. Moreover, while limited sample sizes did not allow for simultaneous analyses of the remittance behavior by SES and generational status, background analysis did reveal that the second and third-generation immigrants tend to have higher SES levels than the $1^{\text {st }}$ and 1.5 generations, yet later generation individuals probably have fewer close family members in the country-of-origin.

A second finding concerns the association between perceptions of social integration and transnationalism. In particular, the less included an immigrant group feels within their receiving society, the more likely they aspire to act transnationally. This is consistent with what Itzigsohn and Giorguli-Saucedo (2002) call reactive transnationalism. Interestingly, in Paris, the most objectively successful and integrated immigrants are, the most transnational they are. We believe this is due to the fact that North African immigrants and their children, even when economically estab- 
lished, feel excluded from mainstream French society and thus engage in reactive transnationalism and nostalgic tourism to North Africa. These respondents also dream of a hypothetical migratory return, although a permanent return of second and third-generation-immigrants rarely occurs for structural and cultural reasons (Castañeda, 2013). In accordance with the reactive transnationalism perspective, immigrants with low social standing in El Paso, New York City, and especially in Paris, engage in more transnational practices to escape their exclusion.

A third finding relates to the influence of SES on the frequency of visits to the country-of-origin. Even before the economic crisis, Latin American immigrants reported in larger numbers a desire to return to their places of birth. Among all groups observed and surveyed, Mexican professionals and graduate students, along with North African business owners, showed the highest level of transnationalism in terms of number of visits and contact with their home countries. This was aided by their socioeconomic success due to integration into their receiving societies. Thus, different types of transnationalism vary according to the position that immigrants and their descendants have in their host societies.

A fourth finding relates to desire for permanent return migration. The processes and behaviors of transnationalism are also relevant to different immigrant incorporation regimes. Thus, why immigrants look "back home" is strongly affected by their level of structural and subjective integration into their new places of residence. Significant transnational activity, in the form of self-identification, visits, and remittances is demonstrated among later generations of French citizens of North African descent who often do not speak Arabic, but may feel the need to frequent a place where they perceive themselves as having more esteem and respect. This speaks clearly about their social position in France. As such, transnational behavior among North Africans in Paris is reflective of the reactive transnationalism hypothesis.

In sum, the data provided in this comparative analysis adds to the evidence for the existence of a reactive transnationalism among immigrants and their children when they do not have a positive integration experience. Generally, the different transnational behaviors - remittances, visits to the home country, and desire for return migration - point to variations in transnational patterns in the three locations. In particular, we argue that in Paris there are more indications of reactive transnationalism while in New York City there is more evidence of a resource based transnationalism. We also proposed a new typology - border transnationalism - to describe transnational behavior in El Paso. 


\section{Acknowledgments}

Data for El Paso was collected with support from the National Institute on Minority Health and Health Disparities, Award Number P2oMDoo2287. The content is solely the responsibility of the authors and does not represent the views of the National Institute on Minority Health and Health Disparities or the National Institutes of Health. This paper was presented in 2012 at the workshop "Migrant Transnationalism, Integration and Return" at Erasmus University, Rotterdam. For very useful feedback and suggestions, we thank Linda Bakker, Ozge Bilgili, Godfried Engbersen, Tineke Fokkema, Uzi Rebhun, Melissa Siegel, and Jessica Sperling. Howard Campbell and Josiah McC. Heyman provided insightful comments. Annie Rhodes helped cleaning variables and with coding and. We thank three anonymous reviewers for their useful comments and suggestions. Finally, we thank the editors for all their help throughout the process.

\section{Notes}

1. " [C'est l'histoire d'une semaine au bled qui s'achève. Enfin, presque reste demain] Gamin, je faisais tout pour ne pas venir ici...Un mois à 10oom d'altitude, sans eau ou électricité; l'impression de vivre un enfer. Aujourd'hui, il n'y a pas une année où je me dis Bordel comment vas-tu trouver dans ta vie d'abruti quelques jours pour venir saluer la terre de tes ancêtres... Un besoin viscéral de me retrouver là, de retrouver les odeurs, de retrouver tous ces sons qui construisent une mémoire, d'entendre Maéva, une gamine de 5 ans, ma voisine me parler en kabyle, cette belle langue, un mix d'anglais et d'anglais... de voir le sourire de Maéva alors qu'elle dévore les bonbons de France. Et puis de me poser sur une terrasse de café et regarder droit devant moi; découvrir, comme si c'était la première fois ces montagnes, majestueuses et fières... [Et puis j'ai pensé à Arnaud Baur et Anissa Reve, qui m’ont accompagné au bled pour fêter mes 40 balais, j'ai pensé Bordel Copé qu'il aille se faire enfiler ce Chien, pas de temps à perdre avec ce bouffon, ici, j'avais mieux, j'avais la classe internationale; des amis comme ça que tu trouves nulle part, sauf si t'as de la chance, et des parents aussi marrants que beau, aussi ouverts que généreux et que tu te dis marliche même si demain tu Crèves comme un cleps au bord de la route, tu auras eu au moins le droit à une semaine inoubliable...Et tu souris, avec tes belles dents toutes blanches, tu pourrais même presque mettre ta main dans le slibard devant tout le monde tellement tu kiffes ta race], t'es même fier de toi parce que tu as compris un peu plus à quoi ça pouvait ressembler le Bonheur »

2. «Magnifique vision de la réalité, le bonheur est à la source, enfin je parle pas pour moi mon pays me déçoit de jour en jour, je retrouve la joie et l'espoir en mes amis du Maghreb qui portent le charme, la vie et tout et tout de cette belle région. Mais bon on se bat pour etre heureux là où Dieu nous a mis! »

3. «Tu as de la chance ..., et j'en suis contente pour toi!j'ai eu la chair de poule en imaginant ton séjour, tellement j'aime mon bled....en ce qui me concerne, j'appréhende d'y aller à 
causes des pressions administratives et autres....ma fille depuis notre dernier séjour a juré de ne plus mettre les pieds la-bàs... malheureusement, je me sens étrangère dans mon pays, comme je me sens étrangère en France à cause toujours des racistes qui dirigent le pays! » Jasmin Khayi

4. «En Algérie il ya eu une régression, vous ne retrouvez pas vos repères. J'ai retourne en 1994 et j'ai pas reconnu ma ville (migration rurale dans la ville).»

\section{References}

Abrego, L. (2009). Economic Well Being in Salvador an Transnational Families: How Gender Affects Remittance Practices. Journal of Marriage and Family, 71 (4), 1070-1085.

Åkesson, L., Carling, J., \& Drotbohm, H. (2012). Mobility, Moralities and Motherhood: Navigating the Contingencies of Cape Verdean Lives. Journal of Ethnic and Migration Studies, 38(2), 23726o. doi: $10.1080 / 1369183 \times .2012 .646420$

Alba, R. D., \& Nee, V. (2003). Remaking the American Mainstream: Assimilation and Contemporary Immigration. Cambridge, MA: Harvard University Press.

Basch, L., Glick Schiller, N., \& Szanton-Blanc, C. (1994). Nations Unbound: Transnational Projects, Postcolonial Predicaments and the Deterritorialized Nation-State. Langhorne, PA: Gordon \& Breach.

Beaman, J. (2012). But madame, we are french also. Contexts, $11(3), 46-51$. doi: 10.1177/1536504212456182 Besserer, F. (2004). Topografías Transnacionales: Hacia una Geografía de la Vida Transnacional. México DF, México: Universidad Autónoma Metropolitana, Iztapalapa; Plaza y Valdez Editores.

Bloemraad, I., \& Provine, D. M. (2013). Immigrants and Civil Rights in Cross-national Perspective: Lessons from North America. Comparative Migration Studies, 1(1), 45-68.

Boehm, D. (2012). Intimate Migrations: Gender, Family, and Illegality among Transnational Mexicans. New York: NYU Press.

Bowen, J. R. (2007). Why the French Don't Like Headscarves: Islam, the State, and Public Space. Princeton: Princeton University Press.

Brubaker, R. (1992). Citizenship and Nationhood in France and Germany. Cambridge, MA: Harvard University Press.

Brubaker, R. (2004). Ethnicity without Groups. Cambridge, MA: Harvard University Press.

Calhoun, C. J. (2003). The Class Consciousness of Frequent Travelers: Toward a Critique of Actually Existing Cosmopolitanism. South Atlantic Quarterly, 1or(4), 869-897.

Campbell, H. (2009). Drug War Zone: Frontline Dispatches from the Streets of El Paso and Juárez (1st ed.). Austin, TX: University of Texas Press.

Campbell, H., \& Lachica, J. G. (2013). Transnational Homelessness: Finding a Place on the US-Mexico Border. Journal of Borderlands Studies, 28(3), 279-290. doi: 10.1080/08865655.2013.863441

Cano, G., \& Delano, A. (2007). The Mexican Government and Organised Mexican Immigrants in The United States: A Historical Analysis of Political Transnationalism (1848 - 2005).Journal of Ethnic and Migration Studies, 33(5), 695 - 725.

Castañeda, E. (2012a). Places of Stigma: Ghettos, Barrios and Banlieues. In R. Hutchison \& B. D. Haynes (Eds.), The Ghetto: Contemporary Global Issues and Controversies (pp. 159-190). Boulder, CO: Westview Press.

Castañeda, E. (2012b). Urban Citizenship in New York, Paris, and Barcelona: Immigrant Organizations and the Right to Inhabit the City In M. P. Smith \& M. McQuarrie (Eds.), Remaking 
Urban Citizenship: Organizations, Institutions, and the Right to the City (Vol. 10, pp. 57-78). New Brunswick, NJ: Transaction Publishers.

Castañeda, E. (2013). Living in Limbo: Transnational Households, Remittances and Development. International Migration, 51(s1), 13-35. doi: 10.1111/j.1468-2435.2012.00745.X

Castañeda, E., \& Buck, L. (2011). Remittances, Transnational Parenting, and the Children Left Behind: Economic and Psychological Implications. The Latin Americanist, 55(4), 85-110. doi: 10.1111/j.1557-203X.2011.01136.X

Castañeda, E., \& Buck, L. (2014). A Family of Strangers: Transnational Parenting and the Consequences of Family Separation Due to Undocumented Migration. In L. A. Lorentzen (Ed.), Hidden Lives and Human Rights in America: Understanding the Controversies and Tragedies of Undocumented Immigration. Santa Barbara, CA: Praeger.

de Haas, H., \& Fokkema, T. (2011). The effects of integration and transnational ties on international return migration intentions. Demographic Research, 25(24), 755-782.

Dekker, B., \& Siegel, M. (2013). Transnationalism and integration: Complements or Substitutes? Maastricht Economic and Social Research Institute on Innovation and Technology (MERIT) Working Papers (Vol. IS). Maastricht, The Netherlands: United Nations University.

Delano, A. (2011). Mexico and its Diaspora in the United States: Policies of Emigration since 1848. New York: Cambridge University Press.

Dreby, J. (2010). Divided by Borders: Mexican Migrants and their Children. Berkeley, CA: University of California Press.

Dufoix, S. (2008). Diasporas. Berkeley: University of California Press.

Espiritu, Y. L. (1997). Asian American Women and Men: Labor, Laws, and Love. Thousand Oaks, CA: SAGE.

Fitzgerald, D. (2009). A Nation of Emigrants: How Mexico Manages its Migration. Berkeley, CA: University of California Press.

Foner, N. (1997). The Immigrant Family: Cultural Legacies and Cultural Changes. International Migration Review, 31(4), 961-974.

Foner, N. (2000). From Ellis Island to JFK: New York's Two Great Waves of Immigration. New Haven, CT: Yale University Press; Russell Sage Foundation.

Gamio, M. ([1930] 1971). Mexican Immigration to the United States: A Study of Human Migration and Adjustment: Dover Publications.

Glenn, E. N. (2002). Unequal Freedom: How Race and Gender Shaped American Citizenship and Labor. Cambridge, MA: Harvard University Press.

Glick Schiller, N. (2003). The Centrality of Ethnography in the Study of Transnational Migration: Seeing the Wetland instead of the Swamp. In N. Foner (Ed.), American Arrivals. Santa Fe, NM: School of American Research.

Glick Schiller, N., \& Fouron, G. (1998). Transnational Lives and National Identities: The Identity of Politics of Haitian Immigrants. In M. P. Smith \& L. E. Guarnizo (Eds.), Transnationalism From Below (pp. 130-161).

Gmelch, G. (1980). Return Migration. Annual Review of Anthropology, 9(1), 135-159. doi: doi:10.1146/ annurev.an.09.100180.001031

Gordon, M. M. (1964). Assimilation in American Life: the Role of Race, Religion, and National Origins. New York: Oxford University Press.

Guarnizo, L. E., Portes, A., \& Haller, W. J. (2003). Assimilation and Transnationalism: Determinants of Transnational Political Action among Contemporary Migrants. American Journal of Sociology, 108(6), 1211-1248. doi: 10.1086/375195

Heyman, J. M. (2012). Culture Theory and the US-Mexico Border. In H. Donnan \& T. Wilson (Eds.), A Companion to Border Studies (pp. 48-65). Malden, MA: Wiley-Blackwell.

Iskander, N. N. (2006). Innovating Government: Migration, Development, and the State in Morocco 
and Mexico, 1963-2005. Ph.D. Dissertation, Massachusetts Institute of Technology, Boston, MA.

Itzigsohn, J. (2009). Encountering American Faultlines: Race, Class, and the Dominican Experience in Providence. New York: Russell Sage Foundation.

Itzigsohn, J., \& Giorguli-Saucedo, S. (2002). Immigrant Incorporation and Sociocultural Transnationalism. International Migration Review, 36(3), 766-798. doi: 10.1111/j.1747-7379.2002.tboo104.x

Jiménez, T. R. (2010). Replenished Ethnicity: Mexican Americans, Immigration, and Identity. Berkeley, CA: University of California Press.

Kasinitz, P., Mollenkopf, J. H., Waters, M. C., \& Holdaway, J. (2008). Inheriting the City: the Children of Immigrants Come of Age. New York, NY \& Cambridge, MA: Russell Sage Foundation; Harvard University Press.

Kearney, M. (1995). The Local and the Global: The Anthropology of Globalization and Transnationalism. Annual Review of Anthropology, 24, 547-565.

Lacorne, D. (2003). La crise de l'identité américaine : du melting-pot au multiculturalisme. Paris: Galimard.

Levitt, P. (1998). Social remittances: Migration driven local-level forms of cultural diffusion. International Migration Review, 32(4), 926-948.

Levitt, P. (2001). The Transnational Villagers. Berkeley, CA: University of California Press.

Levitt, P. (2007). God Needs no Passport: Immigrants and the Changing American Religious Landscape. New York, NY: New Press.

Levitt, P., \& Waters, M. C. (2002). The Changing Face of Home: the Transnational Lives of the Second Generation. New York, NY: Russell Sage Foundation.

Lucassen, L. (2005). The Immigrant Threat: the Integration of Old and New Migrants in Western Europe since 1850. Urbana: University of Illinois Press.

Marcus, G. (1995). Ethnography in/of the World-System. The Emergence of Multi-Sited Ethnography. Annual Review of Anthropology, 24, 95-117.

Martiniello, M. (2013). Comparisons in Migration Studies. Comparative Migration Studies, 1(1), 722. doi: 10.5117/cms2013.1.mart

Massey, D. S. (1987). The Ethnosurvey in Theory and Practice. International Migration Review, 21 (4), 1498-1522.

Massey, D. S., Alarcon, R., Durand, J., \& González, H. (1987). Return to Aztlan: the Social Process of International Migration from Western Mexico. Berkeley, CA: University of California Press.

Massey, D. S., \& Zenteno, R. (2000). A Validation of the Ethnosurvey: The Case of Mexico-U.S. Migration. International Migration Review, 34(3), 766-793.

Mooney, M. A. (2009). Faith Makes us Live: Surviving and Thriving in the Haitian Diaspora. Berkeley, CA: University of California Press.

Morales, C., Morales, O., Menchaca, A. C., \& Sebastian, A. (2013). The Mexican Drug War and the Consequent Population Exodus: Transnational Movement at the U.S.-Mexican Border. Societies, $1(3), 80-103$.

Morawska, E. (2001). Immigrants, Transnationalism, and Ethnicization: A Comparison of this Great Wave and the Last. In G. Gerstle \& J. Mollenkopf (Eds.), E Pluribus Unum? Contemporary and Historical Perspectives on Immigrant Political Incorporation (pp. 175-212). New York: Russell Sage.

Neuman, W. L. (2011). Social Research Methods: Qualitative and Quantitative Approaches (7th ed.). Boston, MA: Allyn \& Bacon.

Ong, A. (1999). Flexible Citizenship: The Culture Logic of Transnationality. Durham, NC: Duke University Press.

Pasura, D. (2011). Modes of incorporation and transnational Zimbabwean migration to Britain. Ethnic and Racial Studies, 36(1), 199-218. doi: 10.1080/01419870.2011.626056 
Portes, A., Escobar, C., \& Arana, R. (2009). Divided or Convergent Loyalties?: The Political Incorporation Process of Latin American Immigrants in the United States. International Journal of Comparative Sociology, 5o(2), 103-136. doi: 10.1177/0020715208101595

Portes, A., Haller, W. J., \& Guarnizo, L. E. (2002). Transnational entrepreneurs: an alternative form of immigrant economic adaptation 67. American Sociological Review, 67(2), 278-298.

Portes, A., \& Rumbaut, R. G. (2006). Immigrant America: a Portrait (3rd ed.). Berkeley, CA: University of California Press.

Roth, W. D. (2012). Race Migrations: Latinos and the Cultural Transformation of Race. Stanford, CA: Stanford University Press.

Sassen, S. (1996). Losing Control? Sovereignty in an Age of Globalization. New York, NY: Columbia University Press.

Sassen, S. (2001). The Global City: New York, London, Tokyo (2nd ed.). Princeton, NJ: Princeton University Press.

Saxenian, A. (2006). The New Argonauts: Regional Advantage in a Global Economy. Cambridge, MA: Harvard University Press.

Sayad, A. (2004). The Suffering of the Immigrant. Cambridge, UK: Polity Press.

Sayad, A. (2006). L'immigration ou les Paradoxes de l'Altérité: L'illusion du Provisoire (Vol. 1): Editions Liber.

Silverstein, P. A. (2004). Algeria in France: Transpolitics, Race, and Nation. Bloomington: Indiana University Press.

Singer, M. (1999). Studying Hidden Populations. In J. J. Schensul, Margaret D. LeCompte, Robert, Trotter II, Ellen H. Crowley, and Merrill Singer (Ed.), Mapping Social Networks, Spatial Data, and Hidden Populations (pp. 125-191). Walnut Creek, CA: AltaMira Press.

Smith, M. P., \& Guarnizo, L. E. (Eds.). (1998). Transnationalism from Below. New Brunswick, N.J: Transaction Publishers.

Smith, R. C. (1998). Transnational Localities: Community, Technology and the Politics of Membership within the Context of Mexico and U.S. Migration. In M. P. Smith \& L. E. Guarnnizo (Eds.), Transnationalism from Below (pp. 196-238).

Smith, R. C. (2003). Diasporic Memberships in Historical Perspective: Comparative Insights from the Mexican and Italian Cases. International Migration Review, 37(3), 722-757.

Smith, R. C. (2006). Mexican New York: Transnational Lives of New Immigrants. Berkeley, CA: University of California Press.

Snel, E., Engbersen, G., \& Leerkes, A. (2006). Transnational involvement and social integration. Global Networks, 6(3), 285-308. doi: 10.1111/j.1471-0374.2006.00145.x

Soysal, Y. N. (1994). Limits of Citizenship: Migrants and Postnational Membership in Europe. Chicago, IL: University of Chicago.

Suarez-Orozco, C., Todorova, I. L. G., \& Louie, J. (2002). Making Up For Lost Time: The Experience of Separation and Reunification Among Immigrant Families. Family Process, 41(4), 19.

Thomas, W. I., \& Znaniecki, F. (1918). The Polish Peasant in Europe and America: Monograph of an Immigrant Group. Chicago, IL: The University of Chicago Press.

Tilly, C. (2007). Trust Networks in Transnational Migration. Sociological Forum, 22(1).

Vila, P. (2000). Crossing Borders, Reinforcing Borders: Social categories, metaphors, and narrative identities on the U.S.-Mexico frontier (1st ed.). Austin, TX: University of Texas Press.

Weil, P. (2005). Qu'est-ce qu'un français? Histoire de la nationalité française depuis la Révolution (Nouvelle édition revue et augmentée ed.). Paris: Gallimard. 


\section{About the authors}

Ernesto Castañeda, corresponding author. Castañeda is visiting academic at the Centre on Migration, Policy, and Society (COMPAS), University of Oxford, U.K., and at the Zolberg Institute on Migration and Mobility, at the New School for Social Research, in New York City. He has conducted surveys and ethnographic fieldwork in places of migrant origin and destination including the United States, France, Spain, Switzerland, Mexico, Algeria, and Morocco. He compares Latino and Muslim immigrant integration in the U.S. and Western Europe. E-mail: ernesto.castaneda@outlook.com

Maria Cristina Morales, Associate Professor of Sociology, Department of Sociology and Anthropology, University of Texas at El Paso. She is a native of the El Paso del Norte region.

Olga Ochoa is a master student at the University of Texas at El Paso. She was born in El Paso and has moved between El Paso, Texas and Ciudad Juárez, Chihuahua all her life. She is currently working on a curriculum to help individuals at the Juvenile Justice Center of El Paso to reintegrate back into their community. 